Director, Dr. Kirchner, Deputy Director, Mr. Pannier) and of the Bundesverfassungsgericht (Constitutional Court. Director, Dr. Mackert, Deputy Director, Mr. Schneider).

These two months left me with a very positive impression. I admired the collection and the pleasant work conditions which were enhanced by the location of the Institute and the excellent housing accommodations (the Institute is located near the Aussenalster-one of the two lakes in the middle of the City of Hamburg-and an adjoining park. Housing can be arranged in one of the apartments within the Institute building). I learned about law libraries from the perspective of a large, world-renown research law library. Dr. Lansky and Dr. Gödan (Deputy Director) always provided me with good advice. They are both law- and librarytrained. Their expertise confirmed my opinion that great possibilities exist for international cooperation in the law library field. I feel honored to have been a participant in this program and I am thankful to the Max-Planck-Institute for its support.

Claire M. Germain

Reference Librarian

Duke University School of Law, Durham, North Carolina, U.S.A.

\title{
THE NEW ZEALAND LAW LIBRARIANS' GROUP
}

The New Zealand Law Librarians' Group is an informal group, set up in 1977, which maintains contact between the handful of professional law librarians in that country, as well as involving those who have responsibilities in connection with private or "law society" libraries or official publications collections. The group publishes a small newsletter edited by A.J. Edwards, Law Librarian, University of Otago, P.O. Box 56, Dunedin, New Zealand. For further information contact Mr. Edwards.

\section{NIGERIAN INSTITUTE OF ADVANCED LEGAL STUDIES PUBLICATIONS}

The recently established Nigerian Institute of Advanced Legal Studies has commenced the publication of a series entitled the "Occasional Papers". The first four papers of the series, all published in 1979, have been received by our editorial office. They are:

No. 1: Nigeria in Search of Social Justice Through the Law, by Dr. Akimola Agude, the first Director of the Institute (28 pp.). 